\title{
SOME THOUGHTS ON THE RELATIONSHIP BETWEEN MULTINATIONAL CORPORATION STRATEGIES AND THE CHANGING PATTERNS OF INTERNATIONAL TRADE
}

\author{
The Geographical Optimization Principle \\ László Árva - Szabolcs Pásztor - Victoria Pyatanova ${ }^{1}$
}

\begin{abstract}
This paper tries to give a comprehensive summary of multinational corporation strategies in the light of a fast-changing world and the changing patterns of international trade. First, we make a general picture of the impact of globalisation on world economy and international corporations. Later we shed more light on contemporary world economy and international trade with strong focus on the most important patterns of current globalisation tendencies. The paper also tries to identify the room for manoeuvre for corporate adaptation and points to the most important factors of competitiveness. Finally, we call attention to relevant directions to be taken by corporations given the rapidly changing feature of the contemporary world economy and international trade.
\end{abstract}

JEL codes: D24, F61, L6o

Keywords: international trade, global shocks, challenges, MNCs, TNCs, globalization, adaptation

1 Lászlo Árva, Economist and Professor of Economics at ESSCA School of Management. E-mail: laszlo.d.arva@gmail.com.

Szabolcs Pásztor, Economist and Associate Professor at the Department of International Economics and Public Policy Studies of the National University of Public Service. E-mail: pasztor. szabolcs@uni-nke.hu.

Victoria Pyatanova, Economist and Associate Professor of the Department for Financial Management of the Plekhanov Russian University of Economics. E-mail: vpiatanova@mail.ru. 


\section{INTRODUCTION}

Companies today operate in a fast-changing world. The evolving business landscape is constantly posing new challenges and opportunities for corporate players. The most important feature of the companies of our days is that they play their part (design, production, marketing, transportation, HR management, etc.) in a complex world-wide setup. Previously, firms mainly worked in one country, and international business was clustered around their export-import activities only. Today, Trans-National Companies (TNCs) are dominant and their international business activities are not limited to international trade, but they also have complex international investments. By that setup TNCs can optimize their activities geographically, meaning that they enjoy more benefits than earlier isolated companies, which did not have strong international ties through their subsidiaries. However, TNCs face difficulties from time to time; Brexit or the election of Donald J. Trump are unlikely to be the last of global shocks. Volatility will continue all over the globe and companies need to be equipped to deal with it. The firms must accept that many old assumptions are no longer valid, and they need new approaches to do business, and new sets of resources and capabilities. The largest corporations are stepping out of their comfort zone more often than in the past and need to develop resilience. The economic crisis is, at present, one of the most important external factors that affect the operation of companies. It may seem that crises generate nothing but problems for business, however, some companies seem to be capable of utilising the situation to their benefit. Through their flexibility, extensive market research, innovativeness and constant change such companies are equipped to operate and even flourish in the current context.

Our paper tries to give a brief summary of the era of globalisation and multinational corporations as a short overview of economic history. Later, in the hope of understanding the current context better, it summarizes the most important features of current world economy and international trade. We presume that the TNCs' major aim is to increase overall company profit and each company optimizes its goals geographically to achieve it.

Our main method is reviewing Hungarian and international literature related to TNCs and the new trends of globalisation, as well as presenting characteristic examples of the management activities of TNCs based on our research and case studies. We would also present environmental effects on TNCs and try to find solutions to the pollution caused by international companies. 


\section{PROBLEMS OF GLOBALISATION,} TNCS, INCOME TRANSFER, AND THE MIDDLE-INCOME TRAP

Despite the large number of misinterpretations, globalisation has been a very popular and widely researched topic since the last decades of the $2 \mathrm{O}^{\text {th }}$ century. First, we have to point out that we usually refer to two or three loosely related globalisation waves, not only one in the international literature (Berger, 2003; Árva et al., 2013; Benichi, 2003). Besides economic globalisation, some experts usually examine the globalisation process of culture and value systems as well (see for example McLuhan, 1962). The economic aspect of globalisation can be measured by the tendencies of international trade and capital flows and their share in gross domestic product (GDP). When we check the indicators, it becomes clear that there were periods when globalisation developed faster while in other eras, we experienced slower growth. The long time series of economic development are useful for analysing and understanding these tendencies (for the long time series see Maddison, 2007). They indicate properly when globalisation was fast or slow. According to Maddison, the first wave of globalisation was in the period of 1500 and 1600 followed by a significant deceleration. Later, in the long $19^{\text {th }}$ century, from the Congress of Vienna to World War I, globalisation accelerated. Globalisation slowed down again from 1914 to 1970, and a completely new and radical phenomenon emerged from the 1970 .

The year of 1914, the beginning of World War I almost completely slowed down the process of globalisation because at times of animosity a completely different light is shed on trade than in peacetime. In terms of foreign direct investments, the situation was even worse because the properties of foreign (in many cases hostile) citizens and companies were often expropriated by governments without any compensation. After World War I, the miniboom, which started in the early years of the 1920s, was disrupted soon by the Great Depression in 1929. Right after experiencing economic growth again, World War II erupted. Until 1945, when the war ended, restarting globalisation had been out of the question. In theory, there had been the possibility of rekindling the third wave of globalisation just after 1945 but other conditions were missing at that time. First, the Soviet Union and its allies (including China) had become influential in political terms and as the socialist world order opposed globalisation and labelled it a capitalist gamesmanship, globalisation processes were not favoured. Similarly, the newly independent colonies, like India, Indonesia, Vietnam and a couple of others, were biased towards the Soviet model and disliked the reappearance of their former colonizers. Despite the establishment of the Bretton Woods system and the General Agreement of Tariff and Trade (GATT) aiming to dismantle the obstacles of world trade already in 1944 and 1945, globalisation did not continue at the desired pace. 


\subsection{Import Substitution Industrialisation}

There was another reason for not reaching the expected pace of globalisation which paradoxically later led to an even faster and more dynamic pace in the 8 os also introducing new forms of globalisation. This was import substitution industrialisation (ISI) which seduced a number of peripheral countries in the ' 50 . The notion of ISI was developed by Celso Furtado (1956) and Raul Prebisch (1950) in Latin America in the middle of the $20^{\text {th }}$ century. The starting point of Furtado and Prebisch was that in pre-war years Latin American countries (as the other underdeveloped, non-industrialized regions) mainly exported raw materials and agricultural products to North America and Western Europe and purchased industrial products from there. However, the world wars and the great depression hindered those trade links and the core (developed) countries were no longer capable of buying the raw materials and supplying the Latin American countries with industrial products. Latin American economists suggested import should be substituted with domestic products. That was import substitution industrialisation. After laying the theoretical foundations, practical steps were taken, and the policy was applied by several Latin American countries and newly independent former colonies. The Achilles heel of import substitution was the provision of sources and the policy was very costly in general. Sources were provided through foreign loans but as interest rates started to increase during the ' 70 s and ' 80 , the resource of import substitution industrialization dried up. ${ }^{2}$ Owing to the rising interest rates, access to financial sources had become more and more difficult and instalments payable on existing credits - because of rising interest rates - started increasing. As a result, not only the developing but also the socialist countries faced a serious credit crisis.

In hope of solving the credit crisis, a British economist, John Williamson elaborated the so-termed Washington Consensus (Williamson, 1989). The theory was clustered around abandoning the policy of import substitution and promotion of local industry and placing much higher emphasis on foreign direct investments. For example, Debt-Equity Swaps (DES) were suggested by which previous debts would be substituted with properties that could earn significant profit for the new foreign owners. The proposal was exactly the opposite of what the developing countries had represented before. ${ }^{3}$ That was the period when the countries that

2 A number of interesting and useful studies are available on the economic development of Latin America. Among others, we have to highlight the volume of the Latin America Economic Committee of the UN, which contains materials published between 1949 and 1998 (ECLAC, 2016).

3 In the English literature foreign direct investments (FDI) refer to foreign investments in which the foreign owner plays an important role in the operation of subsidiaries. In Hungary slightly different terms were used in the previous decades. 
accepted the recommendations of the Washington Consensus as well as the former socialist countries simply gave up their isolationist strategies and opened up their economies for foreign investments (Solimano-Soto, 2005).

\subsection{The Features of Neo-globalisation ${ }^{4}$, the Geographical Optimisation of Transnational Corporations and Global Value Chains}

Based on the international mobility of trade and labour, traditional globalisation has been developing until the end of the $20^{\text {th }}$ century. In that era FDI and TNCs had not been dominant at all. However, from the end of the 7os, when corporate governance systems started to adopt more and more developed computing solutions and transportation and shipping also became cheaper, the transnational corporations $s^{5}$ having subsidiaries and operating in an integrated way in many countries, became more significant. It was a new wave of globalisation which was basically different from the previous ones and we call it neo-globalisation. An important feature of neo-globalisation was the emergence of TNCs in the world economy, which outsourced their production to lower cost countries and did everything to sell their products at the highest price in the developed economies. Finally, this model successfully applied the principle of buy low and sell high. Based on price differences, multinational corporations could gain extra profit without any significant efforts. In addition, the economic policy of the less developed countries offered tax benefits and special subsidies for multinational corporations. Due to the flow of semi-finished goods, materials, knowledge and other goods and services between different locations (we call this transfer pricing) the multinational corporations gained tax advantage as well, and their extra profit increased further (OECD, 2010).

The transnational corporations can optimise the geographic location of the supply chain by outsourcing the manufacturing activities to low wage countries (mainly developing countries) while the higher value-added sections of the value chain remain in countries with more skilled workers. This optimization can be illustrated by a smiley face curve (Fig. 1.). This was first presented by Stan Shin, the CEO and founder of a Taiwanese company, Acer in one of his presentations in the 90 .

4 Neo-globalization is often referred to as hyperglobalization by some authors.

5 In the relevant literature they usually use the terms multinational corporations and transnational corporations interchangeably, but business economics makes a difference between the two according to their organisational structures (see for e.g.: LASSERRE, 2012; DICKEN, 1998). 
Figure 1

Smiley Face curve of value added in GVCs

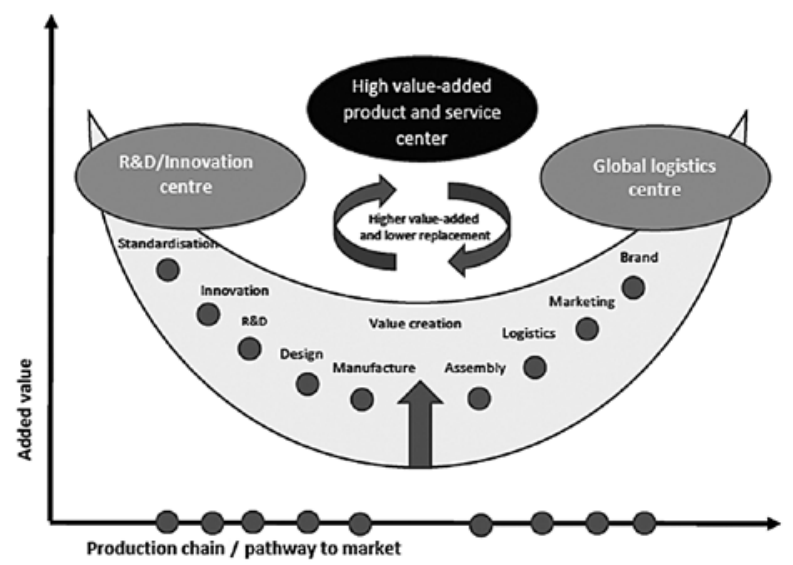

Source: The Smiling Face of Stan Shih, McGill University and the Conference of Canada

Globalisation led by transnational corporations has been criticized by several scholars highlighting the negative effects of draining the resources of less developed countries. Apart from the Nobel laureate Joseph Stiglitz and Paul Krugman, we must mention - among others - the names of Immanuel Wallerstein, Dani Rodrik, Thomas Piketty and Magdolna Csath from Hungary. They have critically analysed globalisation trends and called our attention to the discontents arising from it.

\subsection{The effects of neo-globalisation on the incomes and the middle-income trap}

Starting from the end of the $20^{\text {th }}$ century, in the new model based on international corporations, a new system has evolved built on the network of parent and subsidiary companies all over the world. Owing to these tendencies, half of the world trade had become intra company trade by the end of the $20^{\text {th }}$ century (UNCTAD, 2019). In the developed countries the wages were high, and the products produced, and services provided in other cheap countries were not only designed but sold there. At the same time in the subsidiaries of the TNCs in the less developed, poor countries the wages remained low so that it was possible to produce efficiently the products and services developed in the subsidiaries of the TNCs in the richer countries. This system used to be very favourable for the international corpora- 
tions because production was done in the subsidiary factories in the low wage, poor, less developed countries and the products were sold to customers in the rich, developed, core countries at a higher price. When we make a comparison, we must point to the fact that the old business model by Henri Ford had been just the opposite. Ford offered higher wages to the workers in hope of helping them buy the more expensive Ford cars.

An interesting but in longer terms tragic development of neo-globalisation is the so-termed middle-income trap formulated by Gil and Kharas (2015). According to it, it is easier for low income countries to start development with the help of FDI but later it is more difficult to develop further. They simply get stuck at a low level, performing cheap manufacturing activities. Unfortunately, not much attention has been paid to the relationship between neo-globalisation and the middleincome trap. Among the exceptions we must point to Magdolna Csath, who in the journal of Public Finance Quarterly published an innovative paper (Csath, 2018). The author summed up the evolution of the notion of middle-income trap, called our attention that it is linked to the fact that the developed countries typically outsource the basic manufacturing activities to the poorest, underdeveloped regions. In other words, the parts of the supply chain with more value added are kept in the centre, while the simpler parts with lower value added are transferred to less developed countries. It explains why, besides the large proportion of the less innovative workplaces, it is more difficult to spur competitiveness and accelerate catching-up (Csath, 2019).

Not only whole countries may get stuck in the middle-income trap but local SMEs as well because paying higher wages in the less developed countries does not pose a problem for the TNCs. They can maintain a high margin as they sell their products in the developed countries, but the local SMEs cannot increase their prices as in their major local markets the standard of living is lower, and the locals are usually very price sensitive. According to Árva et al. (2018) SMEs operating in those countries are more exposed to the political élite and owing to the intense competition with the international corporations are more willing to turn to tax evasion. At this point we must raise the following questions.

When and under what conditions and what kind of economic policy can help us avoid the middle-income trap? Is it possible to get rid of the issue? If we look at the economic development of the last decades, we have to point to the fact that only the countries were capable of getting rid of the middle-income trap permanently that

i) were big and strong enough to withstand the pressure of the dictate of the transnational corporations;

ii) had an exact national economic policy;

iii) and it was implemented by the appropriate political will; 
iv) did not give way to despair when breaching those written or unwritten rules of international trade which would be a hindrance to development and getting rid of the middle-income trap.

Finally, it seems that China alone has been showing signs of achieving this aim. Neither the BRICS countries, nor the smaller South-East Asian countries, nor the former European socialist countries (transition economies) have been able to break out of the trap.

\subsection{Social and political effects of neo-globalisation: the trap of rising inequality}

Neoliberal globalisation is just partially successful as the geographic optimisation of the supply chain has significantly increased the effectiveness of the international companies but the undesirable effects are also palpable:

i) the increase in income inequalities across the world (within and across countries as well) never seen before;

ii) the rising income and wealth inequalities have been distorting the independence of the political organisation in certain countries and contributed to the threat of corruption;

iii) owing to the middle-income threat, the semi-developed countries are stuck in manufacturing activities;

iv) globalisation has not eliminated global economy crises, on the contrary, it has increased their severity;

v) anti-globalisation and populist political efforts have been on the rise across the world. ${ }^{6}$

During the previous years, several analysts pointed to the increase in income disparities (for example Credit Suisse (2017) and Oxfam (2019) according to which in 2018 one percent of the population owned more wealth than the rest of the World. We can also mention the well-known analysis of Thomas Piketty about rising income disparities (Piketty, 2015).

We are less likely to make a mistake if we draw parallels between globalisation and the more and more widespread political corruption in the world (see for example the reports of Transparency International). It is also important to keep in mind that for the large group of middle-income countries, further social and economic

6 See in details: ÁrVA (2018). 
development may become an illusion. It is confirmed by the fact that the middleincome trap plays an increasing role in the economic and political debates.

At the same time, globalisation in general is very far from mitigating the economic crises. Since the end of the eighties the crises have become more severe and frequent and the financial and economic crisis of 2008 surpassed other crises and reduced the savings of thousands and millions of people (or to be more exact it redistributed them to the superrich).

It is not a coincidence that owing to the crisis of 2008 and 2013 fears against globalisation and capitalism have become stronger and political forces have appeared representing these opinions. The appearance of Berni Sanders in the USA, Brexit and the anti-EU forces in Europe are indications of the crisis of globalisation from a political aspect. We must conclude that globalisation is not an explicit success story, neither in economic nor in social terms.

\section{EMBRACING CHANGE: TRENDS AND SKILLS REQUIRED}

Analysing the changes taking place in the global environment PriceWaterhouseCoopers distinguished five mega trends ( $\mathrm{PwC}$, 2014).

i) Growing Urban Population. The United Nations predict that in 2050 the urban population will increase up to $72 \%$. As a result, there will be an increasing demand for the resources to build the infrastructure, provide education, ensure security and create jobs.

ii) Global Warming. Climate change combined with population growth will cause resource scarcity.

iii) Demographic Changes. Well developed countries will see aging societies while in other countries the population will grow.

iv) Emerging Markets Gain Power. BRIC countries will gain more influence as a result of population growth, exports and innovation.

v) Advances in Technology. Technological development, in particular, nanotechnology and mobile technology will lead to the emergence of new industries. The barriers to virtual business organizations will be decreased and thus competition and new sources of competitiveness will increase. The development of information and communication technologies will eliminate the negative impact of distributed business locations (Bruks et al., 2011).

There are other important trends that are increasingly affecting how decision makers view their organizations and their futures: automation, the commoditization of knowledge and the fact that we live in so-called ' $V U C A$ ' world - one that becomes increasingly volatile, uncertain, complex and ambiguous. Today the top 
managers of companies worldwide are preoccupied with economic volatility and risk. Organizations are seeing not only economic uncertainty, but more competition and disruption, with new market entrants and radically different business models. The pace of change in the global market continues to accelerate. We can also observe the increase of innovative the changes, when prior experience becomes less useful. Senior leaders are looking for more and better information to help plan a strategy in a world where they are forced to take more calculated risks and encourage innovation in their own organization to drive growth.

Automation and the use of Artificial Intelligence (AI) is a trend that continues to increase. Self-servicing terminals and voice-response systems are replacing the need for routine administrative and simple transaction-based customer service roles. A related trend has been the commoditization of knowledge. The price that people are willing to pay for information continues to fall. For example, the online availability of information about stock and shares has increased to the point that many individuals can manage their investments themselves.

Together, those forces continue to shift the skills and competences required of both leaders and employees. Companies worldwide will need to evolve in at least the following ways:

i) Relational approach. As automation replaces repetitive and routine tasks further, employees must be able to add value in other ways. If, for example, an organization wishes to distinguish itself through its superior customer service, it must ensure that its employees can demonstrate the best human skills in order to develop sustainable relationships with customers. The important skill to be underlined here is 'perspective talking', which is an ability to understand the goals of other people (AF, 2016:65). From business point of view, such conversations will help to identify what another party wants in terms of quantifiable outcomes, such as the price they are willing to pay, and unquantifiable outcomes.

ii) Management of change and dynamic strategy. The pace of change in a VUCA world means that organizations also need to restructure and change more quickly. Nowadays, the strategy should be dynamic, and the key challenge for leaders in managing change is motivating employees to make sure the strategy is executed (Pyatanova, 2011). Today when hiring and promoting employees forward-looking organizations welcome open-minded, mobile and adaptable individuals, rather than ones who are just good at following the existing schedules and processes. In conditions of generalized uncertainty, the capacity for quick real-time and adequate responses to changing situations and forecasts for the future is the source of competitive advantage (Barney, 1991). 
iii) Long-term view and reputation. Many organizations now recognize that operating in a VUCA world means that it is becoming increasingly important to set short-term objectives that lead to true long-term value creation. For example, not paying foreign suppliers on time can improve liquidity but will destroy trust and supplier relationships in the long-term. Therefore, all short-term plans and actions should be aligned with long-term objectives.

\section{COMPETITIVENESS IN A CHANGING ENVIRONMENT}

Today in order to sustain long-term competitive advantage in the global marketplace companies must analyse diverse factors of competitiveness (Table 1). If a company can make use of a variety of factors of competitiveness and provide interaction between its elements, it can build synergy, and as a result it will achieve survival by outperforming its competitors and prospering over time.

\section{Table 1}

\section{Factors of competitiveness of companies}

1 Quality of products and services

2 Unique configuration of resources (particularly intangible)

3 Information, knowledge and talents

4 Dynamic strategy

5 Core competences and dynamic capabilities

6 Cost efficiency

7 Level of profitability higher than of competitors

8 Image and reputation

9 Innovativeness (frequency and scale of innovative initiatives)

10 Advanced leadership, management tools and systems

11 Time needed to execute an order and launch new products (time-based competition)

12 Usage of ICT

13 Situational approach, flexibility \& agility ("organization on the move")

14 Relationship approach and strategies

15 Ability to provide offers based on customers' individual expectations (customer-tailored products) connected to the use of ICT and AI 
Nowadays in the rapidly increasing role of knowledge economy, only an intelligent, flexible and innovative organization has a chance to compete on the market (Bakalarczyk, 2016). Knowledge is one of the most important factors in building a competitive advantage because it can reveal the direction of future trends and opportunities for value creation. Therefore, in order to be competitive, a company should be a learning organization, gaining access to advanced knowledge and diverse information, derived from both internal and external sources. In this respect there is a growing demand for talented employees with creative mind-sets and quest for latest knowledge and continuous development.

Information is regarded as an important strategic resource, determining an organization's success (Olszak, 2016). The development of the Internet, social media, distributed databases, applications, and a variety of mobile devices has caused a huge increase in data: $90 \%$ of all the information ever produced has been created in the past two years (AF, 2016:66). Today the ability to use big data is becoming one of the key components that supports organization's development, helping to monitor various socio-economic phenomena and take effective business decisions.

The adjustment to the changing market and customers' needs require constant observation of what is going on in order to become operative at the right time. On a dynamic market it is difficult to introduce a long-term strategy, companies must adapt to change and do it quickly. Therefore, now more than ever flexibility and agility, accelerated by technological advancement and innovations, can make a big difference on the global marketplace.

Since 1980 s, in competitive struggle, attention has been drawn to companies' available resources, as well as skills and capabilities. Nowadays, considering the role of resources for competitive edge, the great importance of intangible resources should be noted, especially if they are unique for a company, hard to recreate or imitate. Intangibles such as data, branding and talent have now become central to value creation (AF, 2015). The increasing rate and speed of change, ever intense competition and the unpredictability of operational conditions are among the reasons why companies face a necessity to complement internal resources, capabilities and competences, which results in increasing interdependence and need for collaboration. In the circumstances, relationships become embedded in a company's strategic activities.

Relationship strategy is seen as an ongoing and dynamic process of choices about acquiring, building, maintaining or breaking off relationships that are realized under conditions of uncertainty in order to create value, build and maintain the competitive potential (Piwoni-Krzeszowska, 2016). 
However, it should be stressed that the relational strategies area is a broader category than network strategies because a relationship in itself is a set of feelings, attitudes and behaviours towards each of two (or more) players on the market and interactions between them (Piwoni-Krzeszowska, 2014:22).

Thus, the relational approach to strategy involves choices about different types of relationships in order to get a "relationship premium" (Zakrzewska-Bielawska, 2014) evidenced by "an additional profit generated jointly by the parties in the relationship, which could not be achieved by any of the parties alone" (WojcikKarpacz, 2012:64).

The relationship strategy is applicable to strategic choices inside the enterprise, and to various external relationships: with partners, industry regulators, government, competitors etc. When formulating and executing corporate and business strategy the companies have to rest on the "portfolio of relationships" which becomes more and more vital for success. The relationship approach to competitive advantage complements the resource theory with an importance of external relations in creating value and building a competitive edge (Piwoni-Krzeszowska, 2016). In this context, relational strategies for the company's growth are an expression of an adaptation to a selective environment while shaping the environment and conditions of survival (Stańczyk-Hugiet, 2013).

It is also important to mention marketing which is getting more and more important today for the TNCs working on the global market.

\section{GEOGRAPHICAL OPTIMIZATION ACTIVITY OF TNCS}

This part of the paper strives to overview the major characteristics of TNCs. As we will see, TNCs are generally making profit by optimizing different aspects of their economic activities. In our analysis we focus mainly on activities like marketing, environment, taxation (transfer pricing) and human resource management (HR).

\subsection{Geographical Optimization of Marketing}

It is extremely important to apply such up-to-date marketing strategies, which might help the activities of TNCs operating on the world market. It is usual that a TNC design their products in the rich, developed core countries and production is done in the underdeveloped countries, where abundant cheap labour is available. Marketing is generally done all over the world, but it is coordinated from the headquarters, generally from a rich country (Berry et al., 1987).

Products are also commercialized all over the world, some are sold in the rich developed countries at higher prices, some for the rich minority in the developing 
countries, and the rest of their products in the developing countries, at cheaper prices, as a mass product. In that case product segmentation should be done really carefully, meaning that there should be high-end models for the rich consumers going down to the simpler models for the not so affluent customers. Mobil phones can be good examples for that marketing policy, as mobile phones are typical products of TNCs: in this case markets and products are carefully segmented, as the most developed, more expensive products are commercialized mainly in the rich core countries, the less developed cheaper products in the less affluent countries, in the semi-periphery, and the cheapest base products in the poorer countries. It is important that all the products generally have the same brand name (for example: Samsung, iPhone, LG, etc.). It is an important marketing tool because everyone will be speaking about the most expensive, highly sophisticated models, while less wealthy people will necessarily buy the cheaper, less sophisticated products, but they have also inherited part of the prestige of the most sophisticated ones 7 . P. Lasserre has written interesting examples on international marketing activities of TNCs (Lasserre, 2012:218-248). Global marketing might help the global sale of the products, and it is important that significant profit can be realised by a well-organized global marketing strategy.

It is also important that marketing is getting more and more pro and interactive, as on the internet it is relatively easy to follow the buying or reading habits of users, and consequently it is relatively easy to set up a picture of their personality and to propose special advertisements for them. So, if someone regularly follows information on mobile phones or garments, it is sure that next time special ads on these products would be provided for the reader (see in detail: Árva-Deli, 2018). As Artificial Intelligence is getting more and more widespread, the tool would also be used in "targeted marketing". By these new tendencies the privacy of customers is significantly reduced. Google's main activity is related to interactive marketing, so it is not surprising that Google is playing a more and more important role in Artificial Intelligence, self-driving cars, big data analysis, etc. Such optimization of marketing activity can be regarded as an advantageous con-

7 This kind of solution is not new, and it was formerly often used even by local, national companies after WW. II. Typical example was the marketing policy of the Japanese Nikon company, which has given free cameras to the American and European photojournalists reporting from the Korean and later the Vietnam wars. Those products were on the top of the analogue camera technology, and they were very expensive in the shops, so a man-of-the-street generally bought less sophisticated, cheaper models. But the high-end products have given their prestige to the cheaper, popular models. The result was that even men-of-the streets were buying Nikon cameras, simply hoping to borrow the prestige of the expensive, high end cameras. The difference of the today TNC marketing segmentation and the former one is that today segmentation is generally made not only by the revenues of the consumers, but also by their geographical location. 
sequence of the existence of Transnational Companies. The products and services could become more personalized and efficient.

\subsection{Why does pollution arise from the geographical optimization of TNCs?}

TNCs do not pollute voluntarily, but as a large amount of transportation is connected to their activities, pollution of the TNC system is per se very important. It is often remarked that not the TNCs, but the process of globalisation is responsible for increasing pollution. We might also state more precisely, it is neo-globalization and the geographical optimization of the value chain that is responsible for pollution. As different steps of the value chain are realized in different parts of the world, the final product needs lots of transportation, lots of energy and the result is increased pollution (Belal et al., 2015).

It is an interesting contradiction that geographical optimization of the value chain is advantageous at the level of firm profitability, but extremely disadvantageous globally, for the outside world. At the same time the employees of the different subsidiaries are generally largely ignorant about their overall activities: it happens that in a subsidiary of a TNC even the engineers are not aware what they produce. It happened in Hungary that an important Germany-based TNC in the middle of the Great Plain has organized an open day for journalists and the inhabitants of the city, but they were not able to explain the visitors their activity exactly. They simple stated that "some mouldings" arrive from the other end of the world and they work on them, then send them to China, where they are assembled and later sold all over the world. This is a typical TNC subsidiary mentality, where everything is decided in the centre of the company and the rest only fulfil their tasks, and transport raw, semi-finished and finished products all over the world. TNCs often use "environment friendly" slogans, advertising that they recycle waste and so on, but until the geographical optimization of the value chain requires lots of transportation, TNCs would always be responsible for a large part of $\mathrm{CO}_{2}$ emission and other pollution as well (Dooley-Lerner, 1994).

It is only a question of time when global legislation would be introduced in order to reduce emission by TNCs. And that would drastically change their behaviour.

Another issue in terms of pollution by TNCs is that lots of money and efforts can be spared simply by outsourcing some parts of the production to countries where environmental regulations are not as strict than elsewhere or where the regulations are not fully applied (López et al., 2019). It is an example of environmental optimization. Asian, African or the former socialist Eastern European countries were often polluted by TNCs (see e.g. the gold or silver production of Canadian firms in Romania (see: Guardian, 2016). In Eastern Europe pollution by TNCs is 
regarded as an important problem of their activities. Pollution is a clear disadvantage to the TNCs' optimizing activity, and governments should be more active as regulators.

\subsection{Optimizing taxation: transfer pricing and TNCs}

Transfer pricing means the use of special prices inside companies, and as intracompany trade is very difficult to measure objectively, there is a widespread practice to modify those prices in order to decrease profits in the subsidiaries that operate in high tax countries and increase them where corporate taxes are lower (Borkowski, 1997). The purpose is to reduce overall company profits. Tax authorities generally propose to use the "arm's-length-principle" in order to correct price modifications. By the arm's length principle actual prices should be corrected as if the subsidiaries were completely independent from each other. By definition, "transfer prices" refer to "the rules and methods for pricing transactions within and between enterprises under common ownership or control". Although transfer pricing is often inaccurately presented as a practice or technique of tax evasion (transfer mispricing), the term refers to a set of substantive and administrative regulatory requirements imposed by governments on certain taxpayers, companies. That is why it is more precise to write "international tax optimization", similarly to "international cost optimization".

To calculate transfer prices, we should use the arm's length principle (ALP) which is the condition or the fact that the parties to a transaction are independent and on an equal footing. Such a transaction is known as an „arm's-length transaction". In the case of international companies, it is simulating the independence of the parts of TNCs. The OECD made lots of efforts to urge the use of ALP in pricing by TNCs. The OECD has adopted the principle in Article 9 of the OECD Model Tax Convention, to ensure that transfer prices between companies of multinational enterprises are established on a market value basis.

Davies et al. (2014) made a detailed analysis on the transfer pricing of TNCs and have found that in the case of TNCs intra-firm prices may systematically deviate from arm's length prices for two purposes: i) pricing to market, and ii) tax avoidance.

It is an interesting conclusion that "multinational firms may decide not to avoid taxes if the risk to be sanctioned is high compared to the tax gap" (Davies et al., 2014). They have found that "tax avoidance through transfer pricing amounts to about $1 \%$ of the total corporate taxes collected by tax authorities in France. The lion's share of this loss is driven by the exports of 450 firms to ten tax havens". 
At the same time, transfer pricing is as much a natural optimizing activity of a TNC as the geographical optimization of the wages or the natural resources. It is true that similar tax avoidance is present even in the case of SMEs, but it is much easier for the national tax offices to catch and punish them. In case of TNCs, it is easier to avoid national tax offices and their punishments, especially because national governments are not eager in general to hit TNCs as they can leave a country with relative ease. In Hungary we have seen that in a manufacturing assembly unit of a TNC that has been set up in the country to optimize by utilising the cheap labour force and the cheap natural resources, heavy machinery is only fastened to the shop floor with easily soluble bonds, generally by screws, making it easier to dismantle machinery if the company would decide that the given affiliate stops the activity and moves elsewhere. Transfer pricing is a clear-cut example of the negative effects of the TNCs' activity, but hopefully international cooperation of the governments can help in that field. ${ }^{8}$

\subsection{Geographical optimization of HR of TNCs}

The most important aspects of the global optimization by TNCs is the optimization of their HR activity. It means, as we have already stated before, that TNCs are optimizing their value chains and low value-added activities are outsourced to countries where wages are relatively lower, but the more sophisticated activities are kept in the regions where the labour force is better educated and has higher training. This geographical optimization of the activities could have been and sometimes was applied by national companies as well. However, it is not as easy in the case of different countries or even continents, since wages are generally more uniform in one country often regulated by labour legislations. In the countries where there are universal minimal wages, it is not possible to pay different wages in the different parts of the country, and it is also important to note that internal migration (from one part of the country to another one) is generally much simpler than international migration, where language barriers and official borders also hinder the movement of labour (Wright-McMahan, 1994).

However, in the case of TNCs different parts of the value chain can be in different countries, or in different continents. To manage the workers from different countries can necessitate the use of sophisticated intercultural communication and management techniques, but as workers from different countries only meet at the headquarter level in the TNC system, it is not so difficult in reality. Lasserre

8 See: OECD (2017). 
has very important remarks on cross-cultural management in his book (Lasserre, 2012:310-362).

We have seen that there are numerous advantages and disadvantages of geographical optimization by TNCs. On the one hand it can provide more efficient marketing activities, and better, more efficient HR management, but on the other hand transfer pricing can reduce the revenues of the states, and pollution also causes worldwide disadvantage. Though TNCs are often the cause of worldwide negative effects, those effects might be tackled by better cooperation among governments. If this does not happen, important ecological and political repercussions may follow, which should be avoided at any price.

\section{CONCLUSIONS AND RECOMMENDATIONS: A WIN-WIN SITUATION FOR TNCS, THEIR SUBSIDIARIES AND THE HOST COUNTRIES}

The so termed neo-globalisation has introduced completely new phenomena to the economy and society. The major policy of those companies is the geographical optimization of their value chains. The developments have numerous consequences for the companies (both TNCs and SMEs), and for their stakeholders. It is also important that brand new technologies are going to emerge from such TNC and SME networks: one of the most important is Artificial Intelligence and adaptive learning. It is also important that neo-globalization requires new HR techniques as well, as intercultural communication is extremely important for TNCs where the employees are often from completely different cultures.

At the same time, cultural diversity also has its benefits: people from different cultures can be more innovative than people from the same culture, and consequently TNCs can contribute to product differentiation. TNCs have enormous responsibility for the acceptance or rejection of globalization by the population. If TNCs pollute and fail to help local development, cheat in taxation, it is unavoidable that globalization would be rejected by more and more people. That political danger is not in the interests of TNCs, as we have already seen that globalization can only flourish in times of peace.

Finally, let us make some recommendations. It is important that the activities of TNCs are accepted by stakeholders, otherwise their success would only be superficial and short-lived. We should underline that the short-term benefits offered by the geographical optimization of the value chain can destroy the acceptance of globalization and TNCs in the long-term. Consequently, more harmonization is needed with the stakeholders in future. Harmonization is not easy, but it is una- 
voidable in the long-term, and in the long run can create a win-win situation for both TNCs and the people around them, who are the stakeholders.

The stakeholders are very important for the success of TNCs in the time of neoglobalization, and it is extremely important that TNCs establish good and fruitful relations with them. The major topics that should be part of stakeholder harmonization are the following:

i) environment protection,

ii) HR policy of the company,

iii) technological development and spill-over effects (how can technology transfer be urged between a TNC and local SMEs),

iv) wage policy of TNCs,

v) TNCs and the local education and vocational training.

One of the most important ways which can lead to a general acceptance of TNCs is the cooperation with local high schools and universities. For example, in Hungary some TNCs (Audi, Mercedes, and Opel) have already started very fruitful cooperation with local higher educational establishments, creating special faculties of the vehicle industry. Those TNC-backed faculties are at the University of Kecskemét (Neumann János University), the University of Western Hungary, in Györ, and the Technical University of Budapest. Similarly, some important TNCs in Hungary have also started cooperation with high schools and universities of business sciences.

Through such cooperation thousands of Hungarian youngsters are getting to know the company culture of TNCs and learn how to get integrated into it successfully. The TNC-Higher Educational System (HES) cooperation is extremely important in Hungary, where higher education is chronically underfinanced, and a relatively high number of Hungarian students study abroad, while incoming foreign students cannot compensate for the loss caused by the departure of their Hungarian counterparts. Another important point of TNC-HES cooperation is that young students have an important and increasing part to play in the stakeholder system: as young professionals and technical experts they would be more and more important members of the administration. So, investments into TNC-HES cooperation could be very fruitful and profitable for TNCs not only in Hungary, but all over the peripheral countries. 


\section{REFERENCES}

AF (2015): Accountancy Futures - Critical issues for tomorrow's profession. Ed. 11., http://www.acca.lt/ content/dam/ACCA_Global/Members/AB/2015/September/AF\%2011\%20125.pdf.

AF (2016): Accountancy Futures - Critical issues for tomorrow's profession. Ed. 12, https://www.accaglobal.com/content/dam/ACCA_Global/Members/AB/2016/February/AF12.pdf.

Árva, L. - CsAth, M. - GidAY, A. (2018): A hazai kisvállalkozások megerősítése a neoglobalizáció kihívásaival szemben [Stenghtening the Hungarian SMEs against the challenges of neoglobalisation]. Pénzügyi Szemle, 2018/4, 537-555.

Árva, L. - Deli, Zs. (2018): Posztmodern turizmusmarketingtől a „big data” alapú marketingig: új típusú célcsoportképzési módszerek a turizmusban (I. Nemzetközi Turizmusmarketing Konferencia) [From Postmodern tourism marketing to big data based marketing: New type target group defening methods in tourism. (I. International Tourism Marketing Conference)]. Generációk a turizmusban - Tanulmánykötet [Generations in Tourism - Studies]. Pécs: Pécsi Tudományegyetem Közgazdaságtudományi Kar.

Árva, L. - Katona, K. - Schlett, A. (2013): Stages of Globalisation - Alternative Ways from Eastern Europe and the Far East. Praha: Kaligram.

Árva, L. (2018): Economic and Technical Factors Behind the Rise and Fall Economic Globalization and Some Consequences in Hungary. A Historical Perspective. Civic Review (English-Language Edition of Polgári Szemle), 14, Special Issue, 275-289, DOI: 10.24307/psz. 2018.0418.

BAKAlARCZYK, S. (2016): Management of Sustainable Innovation. Risks and Opportunities - in Search of Equilibrium. Cracow, University of Economics, 9-25.

BAldwin, R. (2016): The Great Convergence - Information Technology and the New Globalisation. New York: Harvard University Press.

BARney, J. (1991): Firm's resources and sustained competitive advantage. Journal of Management, $17,99-120$.

Belal, A. R. - Cooper, S. M. - Khan, N. A. (2017): Corporate Environmental Responsibility and Accountability: What Chance in Vulnerable Bangladesh? Critical Perspectives on Accounting, 33(1), 44-58.

Benichi, R. (2003): Histoire de la Mondialisation. Paris: Vuibert.

Berger, S. (2003): Notre première mondialisation: Leçons d'un échec oublié. Paris: Seuil.

Berry, B. J. L. - Conkling, E. C. - RAY, D. M. (1987): Economic Geography: Resource Use, locational choices, and regional specialization in the global economy. Englewood Cliffs, NJ: Prentice-Hall.

BoRkowski, SUSAN C. (1997): Factors motivating transfer pricing choices of Japanese and United States transnational corporations. Journal of International Accounting, Auditing \& Taxation, $6(1), 25$.

Bruks, I. - Weatherston, J. - Wilkinson, G. (2011): The International Business Environment: Challenges and Changes. Harlow: Prentice Hall.

Credit Suisse (2017): Global Wealth Databook 2017. Credit Suisse, November, http://publications.credit-suisse.com/tasks/render/file/index.cfm?fileid=432759CA-oA73-57F6-04C67EF7EE506040 (accessed: 12 December 2018).

Csath, M. (2018): Tudás- és innovációalapú versenyképesség [Knowledge and Innovation-based Competitiveness]. Pénzügyi Szemle, 2018/1, 65-79.

Csath, M. (2019): Közepes jövedelmi csapda vagy fejlettségi csapda és a költségvetési hatások [Middle-income trap or development trap and the budget effects]. Pénzügyi Szemle, 2019/1, 29-48. 
Davies, R. B. - Martin, J. - Parenti, M. - Toubal, F. (2014): Knocking on Tax Haven's Door: Multinational Firms and Transfer Pricing. UCD Centre for Economic Research Working Paper Series, 5132.

Dicken, P. (1998): Global Shift: Transforming the World Economy. $3^{\text {rd }}$ Edition. London: The Guilford Press.

Dooley, R. S. - Lerner, L. D. (1994): Pollution, profits, and stakeholders: The constraining effect of economic performance on CEO concern with stakeholder expectations. Journal of Business Ethics, 13(9), 701-711.

ECLAC (2016): ECLAC Thinking, Selected Texts, 1948-1998. Santiago: ECLAC. 520 p.

Furtado, C. (1956): Uma economia dependente. Rio de Janeiro: Ministério da Educação e Cultura.

Jones, A. (2016). Geographies of Production III: Economic Geographies of Management and International Business. Progress in Human Geography, DOI: 10.1177/0309132516680756.

Giday, A. - ÁRvA, L. (2018): A méretfüggő vállalati adózás: a kkv-k megvédése a globalizáció negatív hatásaitól [The size-dependent corporate taxation: protecting the SMEs frm the negative effects of globalisation]. Polgári Szemle, 14(1-3), 180-192.

Gill, I. S. - Kharas, H. (2015): The Middle-Income Trap Turns Ten. Paper presented at the $37^{\text {th }}$ PAFTAD Conference, Singapore, June $3-5$.

Guardian (2016): Romanian village blocks Canadian firm from mining for gold. In: https://www. theguardian.com/world/2016/jan/14/romanian-village-blocks-canadian-firm-mining-for-gold. Retrieved at 1oth August, 2019.

Insead (2019): The End of Globalisation? https://knowledge.insead.edu/node/5046/pdf (accessed: 18 December 2018).

Clausing, Kimberly, A. (2003): Tax-motivated transfer pricing and US intrafirm trade prices. Journal of Public Economics, 87, 2207-2223.

Lasserre, P. (2012): Global Strategic Management. $3^{\text {rd }}$ Ed. New York: Palgrave Macmillan.

López, L. A. - Cadarso, M. A. - Zafrilla, J. - ArCe, G. (2019): The carbon footprint of the US multinationals' foreign affiliates. Nature Communications, 10:1672, https://www.nature.com/articles/s41467-019-09473-7 (accessed: 14 August 2019).

Maddison, A. (2007): Contours of the World Economy, 1-203o AD: Essays in Macro-Economic History. Oxford: Oxford University Press.

Mantrala, M. K. - Kanuri, V. K. (2018): Marketing Optimization Methods. In Mizik, N. - HansSENs, D. M. (eds.): Handbook of Marketing Analytics. Methods and Applications in Marketing Management, Public Policy, and Litigation Support. Cheltenham, UK - Northampton, MA, USA: Edward Elgar Publishing, 324-370.

McLuhan, M. (1962): The Gutenberg Galaxy: The making of Typographic Man. Toronto Univ. of Toronto Press.

OECD (2010): Transfer Pricing Methods, https://www.oecd.org/ctp/transfer-pricing/45765701.pdf, July (accessed: 20 June 2019).

OECD (2017): Transfer Pricing Guidelines for Multinational Enterprises and Tax Administrations. Retrieved: https://www.oecd.org/tax/transfer-pricing/oecd-transfer-pricing-guidelines-formultinational-enterprises-and-tax-administrations-20769717.htm.

Olszak, C. M. (2016): Big Data - Opportunities and Challenges for Organizations. Risks and Opportunities - in Search of Equilibrium. Cracow University of Economics, 113-128.

OXFAM (2019): Extreme Inequality and Poverty Reports, www.oxfam.org (accessed: 15 May 2019).

Piketty, T. (2015): Capital in the Twenty-First Century. Reprint Edition. Belknap Press: An Imprint of Harvard University Press, 816. 
PiwONI-KRZeszowsKa, E. (2016): Relationship strategies as a contemporary trend of thinking about strategy. Effectiveness and Competitiveness of Modern Business. Concepts - Models - Instruments. Cracow University of Economics, 15-24.

Piwoni-KrzeszowsKa, E. (2014): Zarządzanie wartością relacji przedsiębiorstwa z rynkowymi interesariuszami - aspekt procesu tworzenia wartości. Wydawnictwo Uniwersytetu Ekonomicznego we Wrocławiu.

Prebisch, R. (1950): The economic development of Latin America and its principal problems. New York: United Nations.

Pyatanova, V. I. (2011): Strategiya i konkurentnoe preimuschestvo kompanii. Monografiya, Moscow: Khlebprodinform.

PwC (2014): How Global Changes Can Affect the Business Environment. Enterprise Risk Management Initiative. PricewaterhouseCoopers, https://erm.ncsu.edu/library/article/emerging-risksglobal-trends-affects.

Solimano, A. - Soto, R. (2005): Economic Growth in Latin America in the Late 2oth Century: Evidence and Interpretation. Santiago, Chile: Economic Development Division.

Stańczyk-Hugiet, E. (2013): Dinamika strategiczna w ujeciu ewolucyjnum. Wydawnictwo Uniwersytetu Ekonomicznego we Wrocławiu.

UNCTAD (2019): World Investment Reports, https://unctad.org/en/pages/DIAE/World\%2oInvestment\%2oReport/WIR-Series.aspx (accessed: 11 February 2019).

Williamson, J. (1989): What Washington Means by Policy Reform? In Williamson, J. (ed.): Latin American Adjustment: How Much Has Happened? Washington D.C.: Peterson Institute for International Economics.

Wójcik-KaRpaCz, A. (2012): Zdolność relacyjna $w$ tworzeniu efektów współdziałania małych $i$ średnich przedsiębiorst. Warszawa: Szkoła Główna Handlowa Oficyna Wydawnicza.

World Trade Organization (WTO). World Trade Statistical Review 2016, https://www.wto.org/english/res_e/statis_e/wts2016_e/wts2016_e.pdf.

Wright, P. - McMahan, G. - McWilliams, A. (1994): Human resources and sustained competitive advantage: A resource-based perspective. International Journal of Human Resource Management, 5, 301-326.

ZaKrZewska-Bielawska, A. (2014): Ewolucja szkót strategii : przegląd głównych podejść i koncepcji. Zarzadzanie strategiczne: rozwój koncepcji i metod. Red. naukowy: R. Krupski, Prace Naukowe Wałbrzyskiej Wyższej Szkoły Zarządzania i Przedsiębiorczości, 27(2), Wałbrzych. 